\title{
Construction and calibration of weighing lysimeters with an automated drainage system
}

\author{
Arthur C. Sanches ${ }^{1}$, Débora P. de Souza ${ }^{1}$, Fernando C. Mendonça ${ }^{2} \&$ Rodolfo G. Maffei $^{3}$ \\ ${ }^{1}$ Universidade de São Paulo/Escola Superior de Agricultura 'Luiz de Queiroz'/Programa de Pós-Graduação em Engenharia de Sistemas Agrícolas. \\ Piracicaba, SP. E-mail: arthur_carniato@hotmail.com (Correspondig author); dpdsouza@usp.br \\ ${ }^{2}$ Universidade de São Paulo/Escola Superior de Agricultura 'Luiz de Queiroz'Departamento de Engenharia de Biossistemas. Piracicaba, SP. E-mail: \\ fernando.medonca@usp.br \\ ${ }^{3}$ Universidade de São Paulo/Escola Superior de Agricultura 'Luiz de Queiroz'/Departamento de Engenharia Agronômica. Piracicaba, SP. E-mail: \\ rodolfo.maffei@usp.br
}

\section{Key words: evapotranspiration water balance water consumption}

\begin{abstract}
A B S T R A C T
Quantification of the drained volume is one of the difficulties involved in using weighing lysimeters. Typically, this volume is measured by accessing a moat at the base of a lysimeter. However, it is not feasible to install the moat in small devices. Thus, the aim of this study involves developing, installing, calibrating, and checking the efficiency of small weighing lysimeters with automated drainage systems to test their functionality in field conditions. Each lysimeter is composed of a round PVC water tank with a diameter of $1.22 \mathrm{~m}$ and a depth of $0.58 \mathrm{~m}$ that is placed over a metal frame with three electronic load cells with the nominal capacity of each cell corresponding to $500 \mathrm{~kg}$. The drainage system is composed of a small reservoir with a volume of $10 \mathrm{~L}$, a weighing structure composed of a load cell with a nominal capacity of $30 \mathrm{~kg}$, and an automatic solenoid valve driven by a device coupled to a data logger that records the data from the lysimeter and from the drainage system. Two calibrations are performed for the lysimeter as well as the drainage system to obtain equations with significant correlations $\left(\mathrm{R}^{2}>0.9999\right)$. The drainage system was activated several times during the tests after receiving approximately $63.4 \mathrm{~L}$ of water from rainfall, and this in turn indicated a good performance.
\end{abstract}

\section{Palavras-chave:} evapotranspiração balanço hídrico consumo de água

\section{Construção e calibração de lisímetros de pesagem com sistema automático de drenagem}

\section{R E S U M O}

Uma das dificuldades na utilização de lisímetros de pesagem é a quantificação do volume drenado. Usualmente, tal volume é medido por meio de um fosso de acesso em sua base, cuja instalação é inviável em lisímetros de pequenas dimensões. Assim, este trabalho objetivou desenvolver, instalar, calibrar e verificar a eficiência de lisímetros de pesagem com sistemas de drenagem automatizados testando sua funcionalidade no campo. Cada lisímetro foi composto de uma caixa d'água circular de PVC, com 1,22 $\mathrm{m}$ de diâmetro e profundidade de $0,58 \mathrm{~m}$, montada sobre uma estrutura metálica com 3 células de carga cada uma com capacidade nominal de $500 \mathrm{~kg}$. O sistema de drenagem foi formado por um pequeno reservatório com capacidade de $10 \mathrm{~L}$, uma estrutura de pesagem composta por uma célula de carga com capacidade nominal de $30 \mathrm{~kg}$ e uma válvula solenoide acionada automaticamente por um dispositivo eletrônico acoplado a um datalogger, que registrou os dados de ambos, do lisímetro e do sistema de drenagem. Foram realizadas calibrações de dois lisímetros e sistema de drenagem, cujos resultados foram equações ajustadas com correlação significativa $\left(\mathrm{R}^{2}>0,9999\right)$ para ambos. Durante os testes, o sistema de drenagem foi acionado várias vezes após receber aproximadamente 63,4 L de água por precipitação, apresentando bom desempenho. 


\section{INTRODUCTION}

Evapotranspiration (ET) corresponds to the sum of evaporation (E) and transpiration ( $\mathrm{T}$ ) processes in vegetated surfaces that occur simultaneously, and it is often difficult to separate the two physical processes (Carvalho et al., 2007). The knowledge of ET forms a fundamental basis for designing and managing irrigation systems (Carvalho et al., 2013).

Several devices and methods including lysimeters can be used to determine ET. Weighing lysimeters include a device that is composed of load cells and a support structure that is used to measure the weight variation in a soil block placed inside a box, and the weight difference between income water (irrigation and rainfall) and outcome water (plant consumption and drainage) results in water consumption (Campeche et al., 2011). This type of a lysimeter provides reliable estimates if basic assembly requirements are satisfied (Allen et al., 2011), and it forms a standard method for calibrating other ET estimation methods (Faria et al., 2006).

Water drained from the weighing lysimeter can be measured in several ways. A method that is widely used in large lysimeters involves storing water in a reservoir below the lysimeter with access through a moat (Campeche et al., 2011). The drained water is manually measured. It is not feasible to implement the moat on small lysimeters. Instead, Carvalho et al. (2007) and Miranda et al. (1999) removed the drained water with a manual suction pump and quantified it by using a graduated recipient albeit with low precision data.

Vellame et al. (2012) examined a constant groundwater table and a weighing lysimeter by removing the drained water with a hose and controlling it with a water displacer. However, they faced difficulties with respect to automating the readings. Another drain option was attempted by Mariano et al. (2015) by using a system with mass conservation characteristics similar to a water mill. The system consisted of a PVC pipe and a buffer that emptied the tube when it reached its maximum volume due to the fulcrum that was installed in an eccentric position.

Although the system worked well, there are other possibilities for drainage systems and data logging. The present study aims to install, calibrate, and check the efficiency of weighing lysimeters with automated drainage systems to test its functionality in field conditions.

\section{MAterial AND Methods}

The experiment was conducted in Piracicaba, SP in an area located on the campus of ESALQ/USP (Latitude 22 $42^{\prime} \mathrm{S}$; Longitude $47^{\circ} 38^{\prime} \mathrm{W}$; Altitude $546 \mathrm{~m}$ ) in which four weighing lysimeters were built with automated drainage systems. The soil of the area is classified as Nitosol Red Eutroferric Latosolic, based on the Brazilian system of soil classification (EMBRAPA, 2006) that was in fallow at the time of the drainage systems calibration.

In order to install the lysimeters, the soil was manually withdrawn in an area with a diameter of $1.5 \mathrm{~m}$ and a depth of $1.0 \mathrm{~m}$ with $10 \mathrm{~cm}$ deep layers to retain the original soil characteristics. Additionally, soil samples were taken during the excavation process to obtain the soil water retention curve and determine soil bulk density.
The brickwork wrap structure of each lysimeter included an internal diameter of $1.3 \mathrm{~m}$ and a depth of $1.0 \mathrm{~m}$ deep (Figure 1). The shape of each lysimeter box was circular, and it was composed of rigid PVC with a high resistance per volume unit (Lima et al., 2013; Howell, 2004). The top and base diameter of the box corresponded to 1.22 and $0.95 \mathrm{~m}$, respectively, with a height of $0.58 \mathrm{~m}$ and a volume of $500 \mathrm{~L}$. Each box was disposed over a circular steel metal plate with a thickness of $1 / 4$ in $(0.006$ $\mathrm{m}$ ) and a steel beam triangle with fastening points for the three load cells (Lima et al., 2013).

The drainage process was performed in the background at the asymmetric center of the lysimeter box, and the drained volume was laid up in a reservoir with a volume of $10 \mathrm{~L}$ (Figure 2). The drainage system was composed of a container and a weighing device, and the drainage was automatically activated by a solenoid valve.

The outer walls protected the lysimeter and were built with common bricks, and the support base of the triangular structure was composed of three concrete pillars with iron trusses corresponding to H8 type 5/16". Each lysimeter had three load cells, namely ALFA model I - Shear Bean, with an individual nominal capacity of $500 \mathrm{~kg}$. The drainage system of each lysimeter included a load cell ALFA GL 30 model

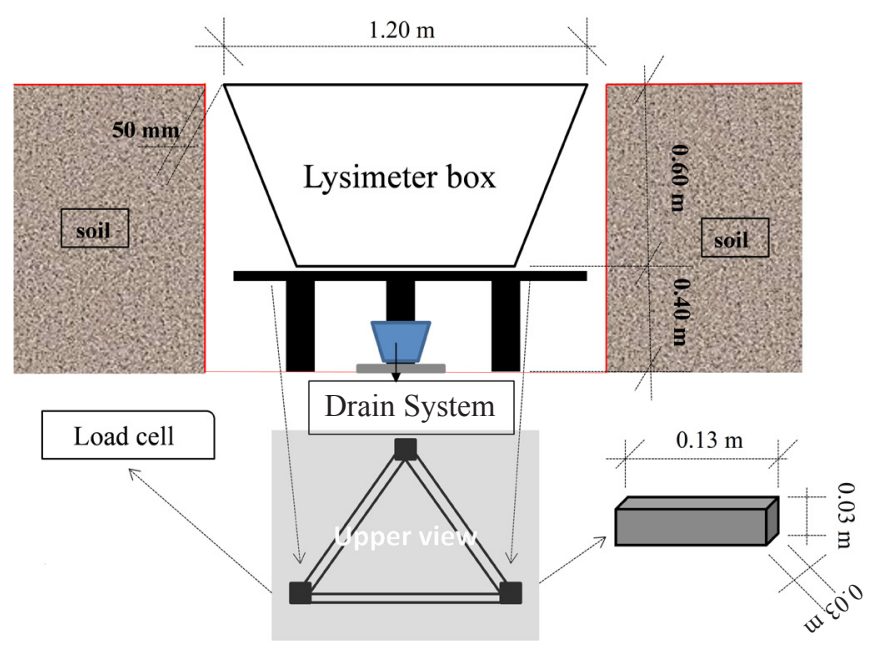

Figure 1. A schematic of the lysimeters installed in the experimental area

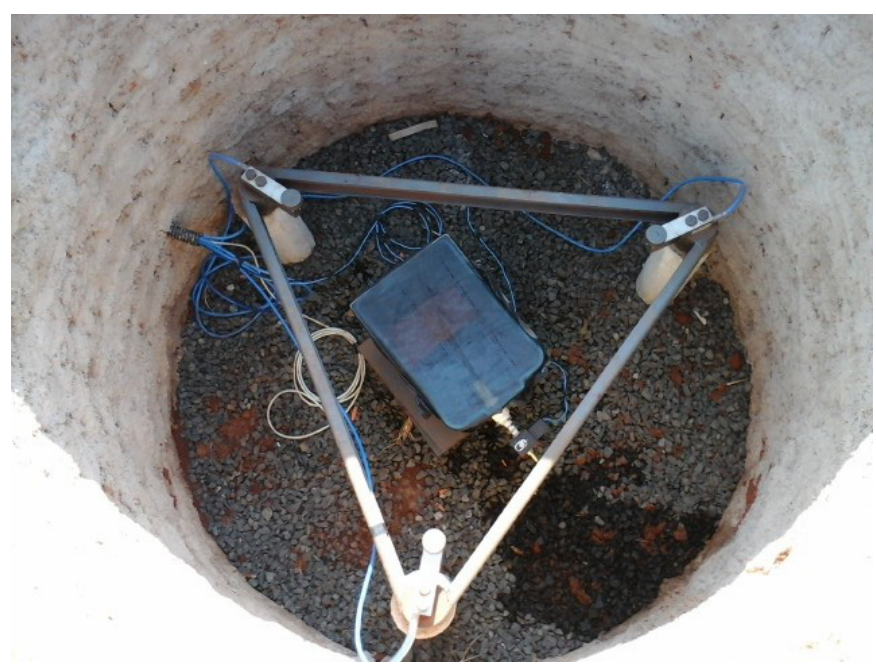

Figure 2. Weighing structure of the lysimeter and drainage system 
with a capacity of $30 \mathrm{~kg}$ and a solenoid valve from ASCO NUMATICS :

The four boxes were filled by following the same assembly sequence. First, it was placed on a layer of crushed stone \#1 (thickness of $5 \mathrm{~cm}$ ) and covered by a synthetic fabric (Bidim ${ }^{\circ}$ ) and a layer of average sized sand with a depth of $5 \mathrm{~cm}$. Over the layers, the soil previously removed from the site was placed in five layers of $0.10 \mathrm{~m}$ that were arranged in the box according to the original soil layer sequence.

The weighing data were registered by a Campbell ${ }^{\circ}$ model CR 1000 data logger. The data were recorded in millivolts $(\mathrm{mV})$ and converted to kilograms by performing the calibration.

The calibration of the drainage system was performed using preset volumes of water, which were first gradually added and then removed in a similar manner. It is difficult to precisely remove the same volume of added water, and thus 11 points were used during addition of water and 12 points were used during water withdrawal. The use of water for calibration is justified by the fact that the system receives only water. Thus, the calibration process was similar to the system operation performed in field conditions.

After the calibration, when the system was in operation, the volume drained by the lysimeter was collected in the drain and weighed by the load cell until it reached 7.2 L (maximum volume). This volume corresponded to the limit for activating the automatic opening of the solenoid valve, and the closing of the valve occurred at a volume of $3.2 \mathrm{~L}$ (minimum volume), and therefore the system operated in a range of $4 \mathrm{~L}$. The minimum volume used was defined to maintain the water level above the valve nozzle opening and to guarantee the valve closing after the drainage process.

Prior to start the calibration process, the lysimeters remained covered for a week with a system similar to an umbrella to prevent water intake in the soil, ease the drainage and evaporation, and to ensure that the soil exhibited the lowest possible water content. After this period, the lysimeter was uncovered and the calibration was performed in late afternoon to avoid the influence of evaporation. During the calibration process, the climatic data collected at the weather station ESALQ/USP (near the experimental area) exhibited a wind speed of $0.2 \mathrm{~m} \mathrm{~s}^{-1}$, an average air temperature of $31.3^{\circ} \mathrm{C}$, and average relative humidity of $73.9 \%$. The fore-mentioned conditions did not interfere negatively in the calibration process.

Based on previous studies (Faria et al., 2006; Campeche et al., 2011), each lysimeter was separately calibrated by using gravel bags with different and standardized weights corresponding to $2,4,6$, and $10.1 \mathrm{~kg}$ to obtain a total of 36 calibration points for each period (addition and removal).

The gravel bags established as calibration points were randomly added and placed individually until the number of bags corresponded to $58(336.2 \mathrm{~kg})$. The bags were subsequently removed in the reverse order by annotating each point of the calibration curve during the addition and removal of the bags. In all the calibrations, the value without any weight (as measured by the load cell and recorded in millivolts) was considered as the tare weight of the lysimeter. The added weight represented a water depth of $287.6 \mathrm{~mm}$ with respect to the lysimeter surface area of $1.17 \mathrm{~m}^{2}$.

Subsequently, the results were subjected to a linear regression analysis, and thus linear and angular coefficients were generated to determine the precision and accuracy of the equipment.

The drain system and the lysimeters were calibrated to perform a field test over 7 days (from November $28^{\text {th }}$ to December $\left.5^{\text {th }}, 2015\right)$ in which the data were obtained through the lysimeters as well as the drain systems to check system effectiveness. The data obtained during the field test were processed by using regression analysis and using a MS-Excel spreadsheet. The correlation coefficient $\mathrm{R}^{2}$ corresponded to the parameter used to verify the accuracy.

\section{Results AND Discussion}

The calibrations performed for the drainage system at the field exhibited adjustments with significant correlations $\left(\mathrm{R}^{2}>\right.$ 0.999 ) between the weight variation and the voltage response (Figure 3). Both angular and linear coefficients exhibited linear and increasing relationships (Figure 3).

The results indicated that weights applied were closely related to the voltage $(\mathrm{mV})$ as shown in Figure 3 with a degree of linearity and excellent fit without hysteresis. Previous studies by Santos et al. (2008) and Faria et al. (2006) indicated that the hysteresis was considered negligible.

The data was converted from weight to water depth (kg to $\mathrm{mm}$ of water), and the corresponding maximum water depth obtained in the lysimeters calibration was $287.6 \mathrm{~mm}$. The data determined by the calibration of the lysimeters exhibited linear adjustments with high determination coefficient (Figure 4). Several extant studies also observed high coefficients of determination that reached values equal or similar to $\mathrm{R}^{2}=0.99$ (Mariano et al., 2015; Vilela et al., 2015; Carvalho et al., 2013; Lima et al., 2013). Additionally, angular and linear coefficients exhibited similar values in all the lysimeters (Figure 4).

The values of weight (in g) obtained in the field evaluations of the automatic drainage are presented in Table 1. On November $28^{\text {th }}$ (the beginning of the test), the soil exhibited moisture close to the field capacity. After this period, it was observed that a maximum of six drainage events (Drain 3, Table 1, and Figure 5) occurred from November 28, 2015 to December 2, 2015.

The cumulative drain water volume reached $63.4 \mathrm{~L}$ due to the occurrence of rainfall events, and this significantly exceeded the volume of the drain reservoirs. A significant amount of this accumulation occurred in the first two days (54.4 $\mathrm{mm}$ that corresponded to $61.5 \mathrm{~L}$ ). This justifies the drain and the activation of the solenoid valves that occurred within the first three days (Table 1 and Figure 5). Duncan et al. (2016) observed that the drainage occurred immediately after rain started. A similar finding was also observed in the present study. If the drainage system allowed a fast reading of the drainage volume, it can be extended to other types of studies such as solute movement in the soil. 

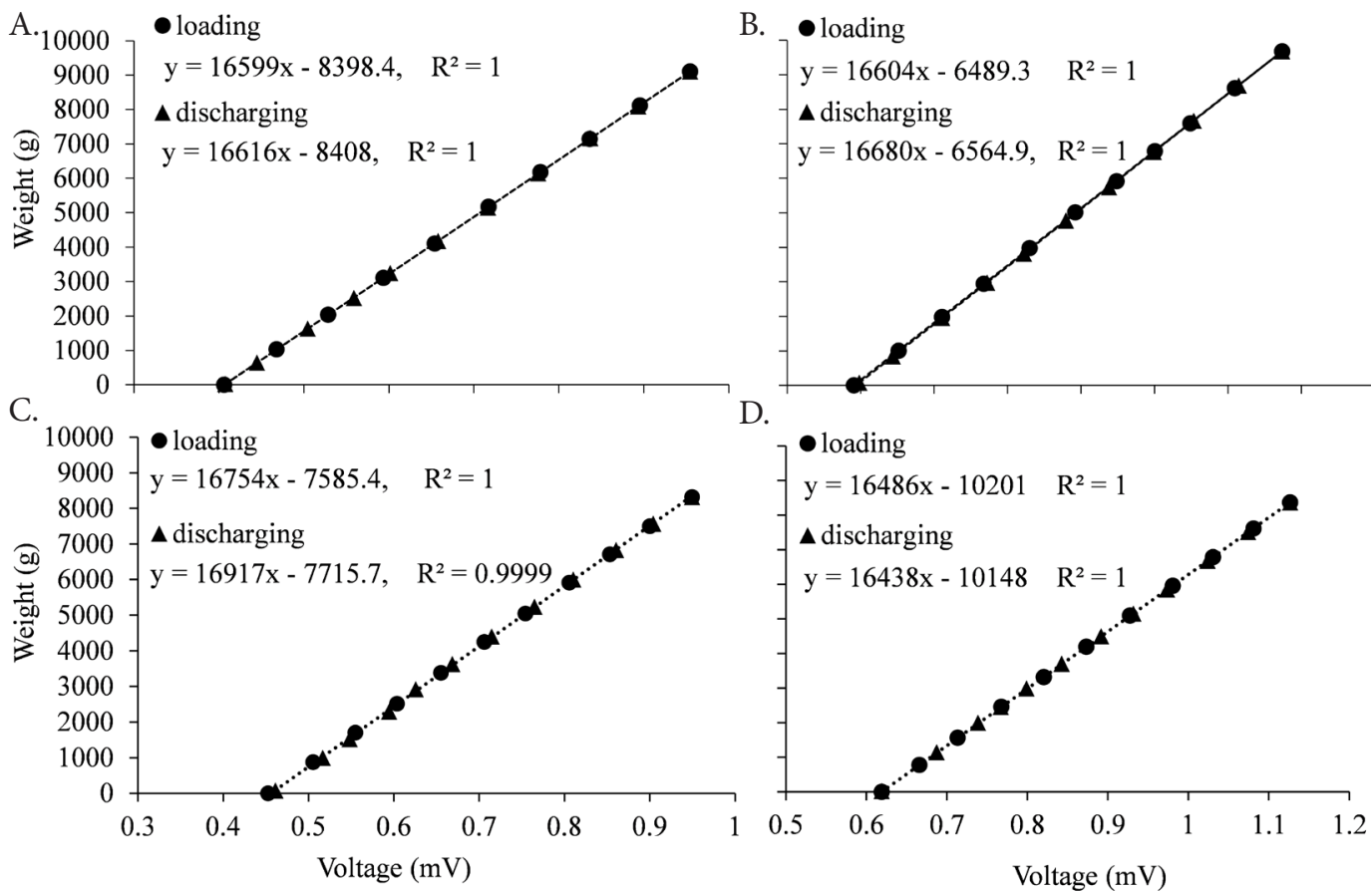

Figure 3. Calibration curves adjustment for the drains. (A) Drain response curve 1; (B) Drain response curve 2; (C) Drain response curve 3; (D) Drain response curve 4
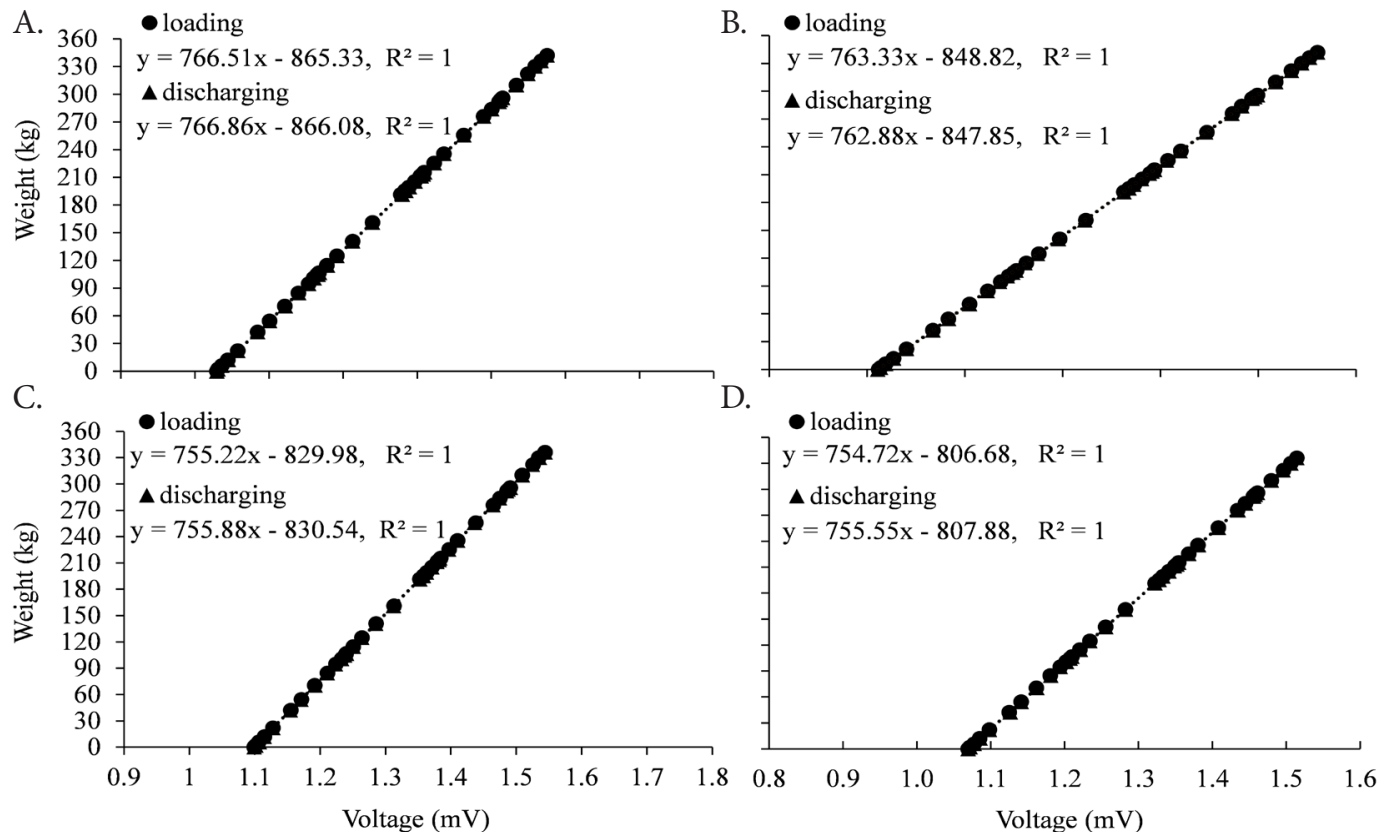

Figure 4. Calibration curves for the lysimeters. (A) Lysimeter 1; (B) Lysimeter 2; (C) Lysimeter 3; (D) Lysimeter 4

Table 1. Weight variations in the drain system over a period of 7 days

\begin{tabular}{|c|c|c|c|c|c|c|}
\hline \multirow{2}{*}{ Date } & \multicolumn{2}{|c|}{$\begin{array}{l}\text { Climatic } \\
\text { data }\end{array}$} & \multicolumn{4}{|c|}{$\begin{array}{c}\text { Average daily weight data } \\
\text { of drains (g) }\end{array}$} \\
\hline & $\begin{array}{l}\text { Temp. } \\
\left({ }^{\circ} \mathrm{C}\right)\end{array}$ & $\begin{array}{l}\text { Precip. } \\
(\mathrm{mm})\end{array}$ & 1 & 2 & 3 & 4 \\
\hline $28 / 11$ & 24.8 & 18.0 & $4090^{3}$ & $4105^{1}$ & $4128^{1}$ & $3938^{2}$ \\
\hline $29 / 11$ & 25.0 & 36.4 & $5256^{5}$ & $5375^{5}$ & $5043^{6}$ & $4764^{4}$ \\
\hline $30 / 11$ & 25.7 & 1.4 & $5072^{2}$ & $4898^{1}$ & $5084^{2}$ & $4838^{2}$ \\
\hline $01 / 12$ & 25.3 & 0.1 & 5975 & 6299 & $4691^{1}$ & 5192 \\
\hline $02 / 12$ & 26.5 & 0 & $6069^{1}$ & $4695^{1}$ & 3638 & 5860 \\
\hline $03 / 12$ & 27.9 & 0.2 & 3600 & 3765 & 4066 & 6042 \\
\hline $04 / 12$ & 27.1 & 0 & 3791 & 4254 & 4316 & 6023 \\
\hline $05 / 12$ & 26.1 & 0 & 3715 & 4293 & 4188 & 5945 \\
\hline
\end{tabular}

1 One actuation of the valve drain; ${ }^{2}$ Two actuation of the valve drain; ${ }^{3}$ Three actuation of the valve drain; ${ }^{4}$ Four actuation of the valve drain; ${ }^{5}$ Five actuation of the valve drain; ${ }^{6}$ Six actuation of the valve drain
As shown in Figure 5, drainage did not occur in the absence of rainfall, and the system stabilized to exhibit a perfect functioning of the automated assembly, which was proven as extremely practical (Macedo et al., 2010). Thus, the automated drainage system reduced the need for hand labor. Popoca et al. (2008) reported the good performance of an automated system for localized irrigation by using a lysimeter equipped with an electromagnetic solenoid valve to open and close the water flow.

The use of automation is highly versatile and allows improvements in the acquisition of experimental data as well as the quality and efficiency of fieldwork by using weighing lysimeters. 


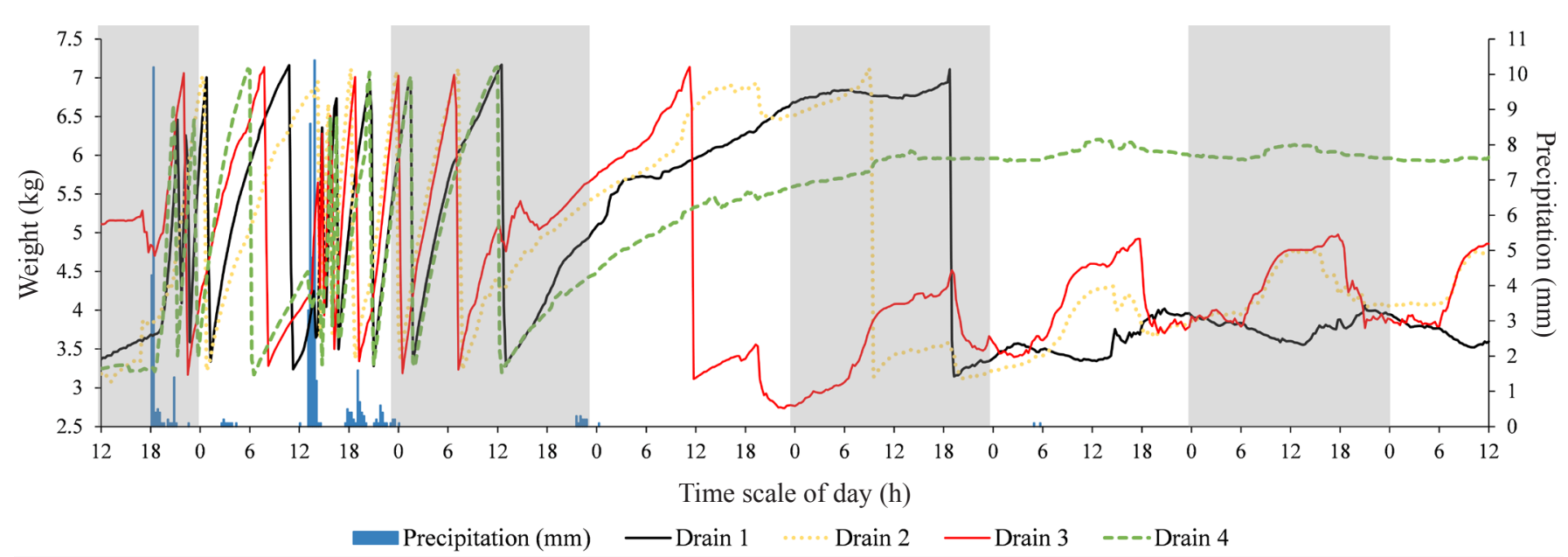

Figure 5. Drainage variation curve from November 28, 2015 to December 5, 2015

\section{Conclusions}

1. The automated systems used in the lysimeters and in the drainage systems exhibited a good performance with high precision and accuracy during data collection.

2. The experiments indicated that the drainage system automation was effective and practical and that it eased the continuous operation of equipment to correspond to an effective measure.

\section{ACKNowledgments}

The authors thank the Sao Paulo State Foundation for Research Support - FAPESP for providing the financial resources necessary for this study, which was a part of the research project $n^{\circ}$ 2012/23002-6.

\section{Literature Cited}

Allen, R. G.; Pereira, L. S.; Howell, T. A.; Jensen, M. E. Evapotranspiration information reporting: I. Factors governing measurement accuracy. Agricultural Water Management, v.98, p.899-920, 2011. https://doi.org/10.1016/j.agwat.2010.12.015

Campeche, L. F. M. de S.; Aguiar Netto, A. O.; Sousa, I. F.; Faccioli, G. G.; Silva, V. de P. R. da; Azevedo, P. V. de. Lisímetro de pesagem de grande porte. Parte I: Desenvolvimento e calibração. Revista Brasileira de Engenharia Agrícola e Ambiental, v.15, p.519-525, 2011. https://doi.org/10.1590/S1415-43662011000500013

Carvalho, D. F.; Silva, L. D. B.; Guerra, J. G. M., Cruz, F. A.; Souza, A. P. Instalação, Calibração e funcionamento de um lisímetro de pesagem. Engenharia Agrícola, v.27, p.363-372, 2007. https://doi. org/10.1590/S0100-69162007000300005

Carvalho, H. de P.; Melo, B. de; Atarassi, R. T.; Camargo, R. de; Silva, C. R. da; Moraes, M. R. B. Desenvolvimento de lisímetros de pesagem na cultura do café. Bioscience Journal, v.29, p.1750-1760, 2013.

Duncan, M. J.; Srinivasan, M. S.; McMillan, H. Field measurement of groundwater recharge under irrigation in Canterbury, New Zealand, using drainage lysimeters. Agricultural Water Management, v.166, p.17-32, 2016. https://doi.org/10.1016/j. agwat.2015.12.002

EMBRAPA - Empresa Brasileira de Pesquisa Agropecuária. Sistema brasileiro de classificação dos solos. Brasília: EMBRAPA, 2006. 306p.
Faria, R. T. de; Campeche, F. de S. M.; Chibana, E. Y. Construção e calibração de lisímetros de alta precisão. Revista Brasileira de Engenharia Agrícola e Ambiental, v.10, p.237-242, 2006. https:// doi.org/10.1590/S1415-43662006000100035

Howell, T. A. Lysimetry. Encyclopedia of soils in the environment. v.2, p.379-386, 2004.

Lima, N. S. da; Montenegro, S. M. G. L.; Albuquerque Filho, J. A. C. de; Silva, E. F. F. e; Montenegro A. A. de A.; Nascimento, A. H. C. do. Desempenho de um lisímetro de pesagem hidráulica com sensor de pressão hidrostática e sistema manométrico. Irriga, v.18, p.540-557, 2013. https://doi.org/10.15809/irriga.2013v18n3p540

Macedo, A. B. M.; Miranda, F. D. de; Gomes Filho, R. R.; Teixeira, A. dos S.; Cavalcante Júnior, J. A. H.; Araújo, H. D. de. Desempenho de um sistema de irrigação automatizado através da tensão de água no solo. Revista Brasileira de Agricultura Irrigada, v.4, p.78-81, 2010. https://doi.org/10.7127/rbai.v4n200410

Mariano, D. C.; Faria, R. T. de; Freitas, P. S. L. de; Lena, B. P.; Johann, A. L. Construction and calibration of a bar weighing lysimeter. Acta Scientiarum Agronomy, v.37, p.271-278, 2015. https://doi. org/10.4025/actasciagron.v37i3.19368

Miranda, F. R. de; Yoder, R. E.; Souza, F. de. Instalação e calibração de um lisímetro de pesagem no projeto de irrigação Curu-Paraipaba, CE. Revista Brasileira de Engenharia Agrícola e Ambiental, v.3, p.107-110, 1999. https://doi.org/10.1590/1807-1929/agriambi. v3n1p107-110

Popoca, C. M.; Marin, F. M. Á.; Nolasco, A. Q.; Kleisinger, S.; Chávez, T. L.; Sáenz, M. E. Sistema de riego automatizado en tiempo real com balance hídrico, medición de humedad del suelo y lisímetro. Agricultura Técnica em México, v.34, p.459-470, 2008.

Santos, F. X. dos; Rodrigues, J. J. V.; Montenegro, A. A. de A.; Moura, R. F. de. Desempenho de lisímetro de pesagem hidráulica de baixo custo no semiárido nordestino. Engenharia Agrícola, v.28, p.115124, 2008. https://doi.org/10.1590/S0100-69162008000100012

Vellame, L. M.; Coelho Filho, M. A.; Coelho, E. F.; Fraga Júnior, E. F. Lisímetro de pesagem e de lençol freático de nível constante para uso em ambiente protegido. Revista Caatinga, v.25, p.153159, 2012.

Vilela, M. da S.; Cabral Filho, F. R.; Teixeira, M. B.; Amaral, A. M.; Vellame, L. M.; Soares, F. A. L. Acurácia de um mini-lisímetro de pesagem eletrônica de baixo custo. Irriga, v.1, ed.esp., p.158-167, 2015. https://doi.org/10.15809/irriga.2015v1n2p158 